\title{
Invited Review: Bovine Studies on Optimal Lengths of Dry Periods ${ }^{1,2}$
}

\author{
K. C. Bachman and M. L. Schairer \\ Department of Animal Sciences, \\ University of Florida, Gainesville 32611
}

\section{ABSTRACT}

Milk production per cow has increased as a result of progressive changes in the genetics and management of the dairy animal population. A management constant during many decades of progress has been the widely adopted dry period length of 51 to $60 \mathrm{~d}$. The scientific basis for that industry standard was examined to assess its validity as the appropriate standard for the modern dairy industry. If subsequent milk yields can be sustained fully after dry periods that are shorter than the current standard, then considerable milk is being forfeited by retaining longer dry periods. Conversely, failure to allow any dry period will result in a significant decrease in subsequent milk synthesis and secretion. Most studies to determine the minimum length of dry period required have involved retrospective analyses of observational data. Only five experiments have been reported in which dairy cows were assigned, at random, to planned 30- and 60-d dry periods. Estimates of the change in subsequent milk production when days dry were decreased from 50 to $57 \mathrm{~d}$ to 30 to $34 \mathrm{~d}$ ranged from a $10 \%$ decrease to a $1 \%$ increase. However, lower yields after shorter dry periods may be partially offset by greater milk yields in the previous lactation if such cows are milked 3 to $4 \mathrm{wk}$ longer. Environmental factors that influence milk production as well as the biological processes that occur within the mammary gland during the nonlactating period must be considered when dry period lengths are compared. Importantly, additional animal trials that specifically assign cows randomly to the dry period lengths to be evaluated are needed to determine optimal dry period lengths for modern dairy cows in differing management scenarios.

(Key words: dry period, milk production, lactation, bovine)

Abbreviation key: $\mathbf{M E}$ = mature equivalent.

Received December 31, 2002.

Accepted May 1, 2003.

Corresponding author: K. C. Bachman; e-mail: bachman@animal. ufl.edu.

${ }^{1}$ Florida Agricultural Experiment Station Journal Series Number R-09252.

${ }^{2}$ Mention of companies or products does not constitute endorsement by University of Florida or Florida Agricultural Experiment Station over similar products not mentioned.

\section{INTRODUCTION}

Milk production per cow has increased as a result of progressive changes that have occurred in the genetics and management of the dairy animal population. In the United States, milk production per cow was 8257 $\mathrm{kg}$ in 2000 (National Agricultural Statistical Service, 2001). Comparable values for 1960, 1970, 1980, and 1990 were $3188,4423,5394$, and $6705 \mathrm{~kg}$, respectively. A management constant throughout those decades of progress has been the widely recommended and adopted dry period length of 51 to $60 \mathrm{~d}$. The scientific basis for that historical industry standard is reviewed herein to assess its validity as the appropriate standard for the modern dairy industry. Industry-wide, considerable amounts of milk are being forfeited if milk yields during the subsequent lactation are sustained fully after dry periods that are shorter than the current standard. Also, additional financial benefit could accrue because a shorter dry period, if proven to be equally effective, would allow for changes in nutritional management that could reduce the amount of stress and the incidence of disorders that dairy cows experience postpartum as they transition into a copious lactating status (Goff and Horst, 1997).

Arnold and Becker (1936) noted that 10 widely used textbooks in dairy husbandry published between 1911 and 1930 recommended that cows have a dry or rest period ranging from 4 to $10 \mathrm{wk}$ in length. The majority of the texts favored 6 to $8 \mathrm{wk}$, depending on the physical condition of the cow. As cited therein, Woodward and Dawson (1926) held that the length of dry period should depend on the quantity of milk a cow produced and upon her condition as regards fatness. Arnold and Becker (1936) also noted that the practice of drying cows as they approach parturition has been developed from the experience of practical farmers and dairymen over more than a century, rather than based on the results of planned experiments.

\section{ORIGIN OF DATA ANALYZED}

Planned experiments, conducted to identify an optimal dry period length, can be assigned to either of two categories: retrospective analysis of observational production data and planned animal trials (Tables 1 and 
Table 1. Retrospective analysis of milk yield (MY) datasets to compare dry period lengths.

\begin{tabular}{|c|c|c|c|c|c|}
\hline Study & Days dry (n) & MY (kg) & $\begin{array}{l}\text { Milk yield } \\
\text { (relative \%) }\end{array}$ & Statistics & Conclusion \\
\hline Arnold and Becker (1936) & $\begin{array}{l}<30\left(9 \mathrm{recd}^{1}\right) \\
31 \text { to } 60(22 \mathrm{recd})\end{array}$ & $\begin{array}{l}2688 \\
3259\end{array}$ & 82.5 & No & $<30$ d dry decrease MY \\
\hline Lee et al. (1961) & $\begin{array}{l}<42(\text { few }) \\
42 \text { to } 60(<2364) \\
\text { Total } 2364 \text { cows } \\
(3435 \mathrm{~kg})\end{array}$ & $\begin{array}{l}\text { NI } \\
\text { NI }\end{array}$ & & No & d dry negligible effect on MY \\
\hline Smith and Legates (1962) & $\begin{array}{l}<40(289 \text { recd }) \\
41 \text { to } 80(2014 \text { recd }) \\
\text { Total } 3071 \text { recd }\end{array}$ & $\begin{array}{l}5706 \\
5773\end{array}$ & 98.8 & No & $\begin{array}{l}\text { d dry equals }<0.1 \% \\
\text { of variance in MY }\end{array}$ \\
\hline Wilton et al. (1967) & $\begin{array}{l}30(\mathrm{NI}) \\
60(\mathrm{NI}) \\
\text { Total } 16091 \mathrm{recd} \\
\text { (>2nd lactation) }\end{array}$ & $\begin{array}{l}5878 \\
5987\end{array}$ & 98.2 & No & $\begin{array}{l}\mathrm{d} \text { dry equals } 4.8 \text { and } 0.6 \% \\
\text { of variance in MY } \\
\text { for } 2 \text { nd and }>2 \text { nd lactation }\end{array}$ \\
\hline Dias and Allaire (1982) & Total 8981 cows & & & & $\begin{array}{l}\text { total MY maximized for } 2 \\
\text { consecutive lactations by } \\
\text { d dry range of } 30 \text { to } 75\end{array}$ \\
\hline Keown and Everett (1986) & $\begin{array}{l}30 \text { to } 39(\mathrm{NI}) \\
50 \text { to } 59(\mathrm{NI}) \\
\text { Total } 689,048 \text { recd }\end{array}$ & $\begin{array}{l}6230 \\
6480\end{array}$ & 96.1 & No & support 50 to $59 \mathrm{~d}$ dry \\
\hline Funk et al. (1987) & $\begin{array}{l}30 \text { to } 39(\mathrm{NI}) \\
60 \text { to } 69(\mathrm{NI}) \\
\text { Total } 174,251 \text { recd }\end{array}$ & $\begin{array}{l}5640 \\
6000\end{array}$ & 94.0 & No & $\begin{array}{l}\text { support } 60 \text { to } 69 \text { d dry } \\
\text { (included previous MY) }\end{array}$ \\
\hline Smith and Becker (1995) & $\begin{array}{l}<39(\mathrm{NI}) \\
50 \text { to } 59(\mathrm{NI}) \\
\text { Total } 123,181 \text { cows }\end{array}$ & $\begin{array}{l}8015 \\
8392\end{array}$ & 95.5 & No & support 50 to $59 \mathrm{~d}$ dry \\
\hline \multirow[t]{2}{*}{ Makuza and McDaniel (1996) } & $\begin{array}{l}30 \text { to } 39(49) \\
50 \text { to } 59(661) \\
\text { Total } 3518 \text { US recd } \\
\text { (2nd lactation) }\end{array}$ & $\begin{array}{l}8221 \\
8629\end{array}$ & 95.3 & Yes & $\begin{array}{l}\text { support } 60 \text { to } 69 \text { d dry } \\
\text { (included previous MY, } \\
\text { previous/current d open) }\end{array}$ \\
\hline & $\begin{array}{l}30 \text { to } 39(244) \\
50 \text { to } 59(722) \\
\text { Total } 3555 \mathrm{ZB} \text { recd } \\
\text { (2nd lactation) }\end{array}$ & $\begin{array}{l}5176 \\
5307\end{array}$ & 97.5 & Yes & $\begin{array}{l}\text { support } 60 \text { to } 69 \text { d dry } \\
\text { (included previous MY, } \\
\text { previous/current d open) }\end{array}$ \\
\hline
\end{tabular}

\footnotetext{
${ }^{1}$ recd $=$ records.
}

2). A critical difference exists between those two experimental approaches when they are used to identify the shortest dry period length that does not result in a decrease in milk yield during the subsequent lactation. When animal trials are conducted, each cow is assigned to a planned dry period length at random irrespective of the amount of milk that she has produced or is producing at the time of drying. Thus, a similar number of cows, with varied genetic ability to produce milk, are assigned to each planned dry period length to be evaluated, i.e. 30 or $60 \mathrm{~d}$.

In contrast, when observational datasets are analyzed retrospectively, the number of records for cows with 30$\mathrm{d}$ dry periods is limited relative to the number of records for cows with 60-d dry periods. More importantly, the cows with dry periods of $30 \mathrm{~d}$ or shorter within those datasets were not assigned at random to have a planned short dry period. Instead, the 30-d and other unplanned 
Table 2. Milk yield (MY) data from planned animal trials to compare dry period lengths.

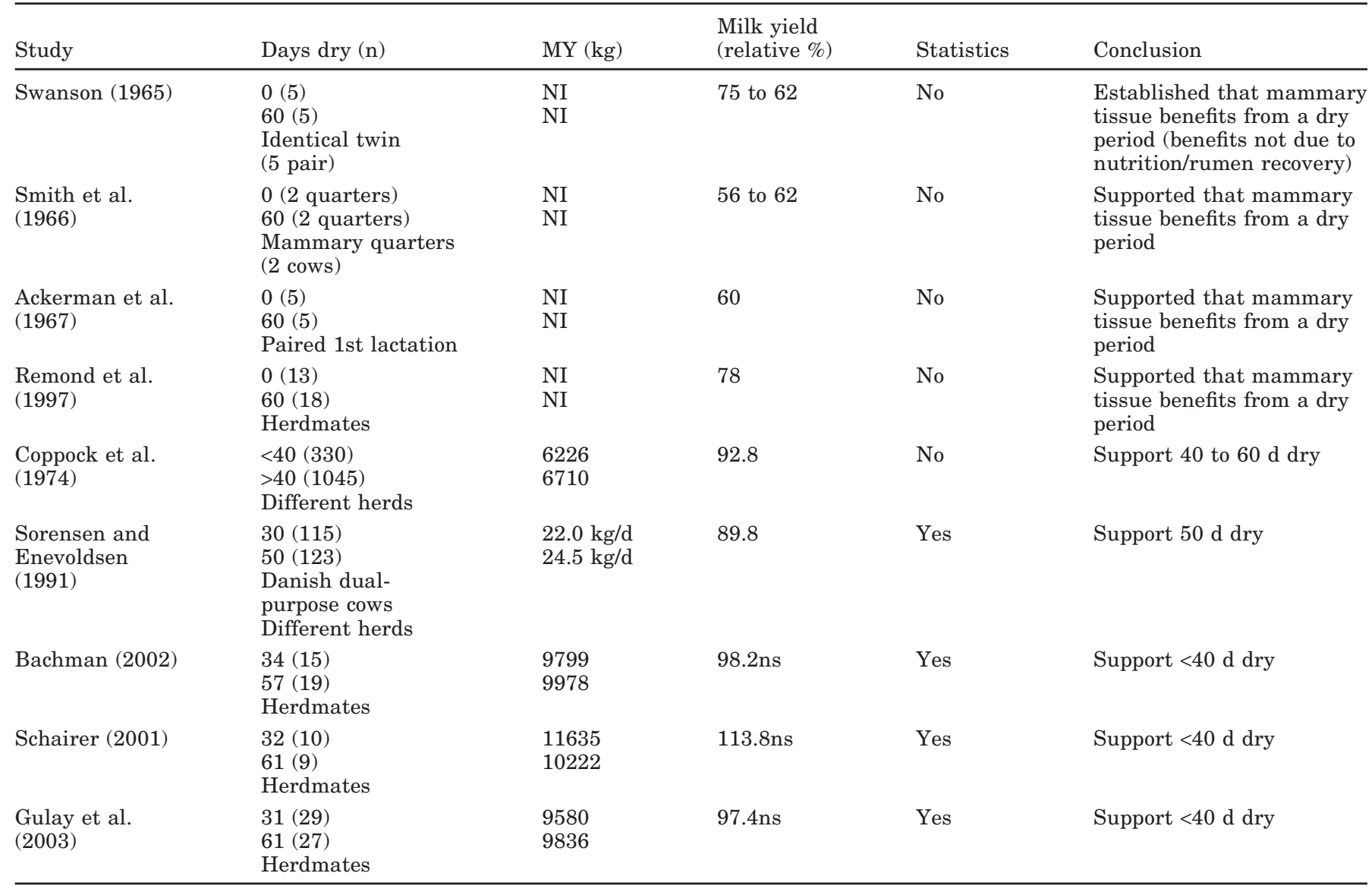

short dry-period categories are composed primarily of a nonrandom population of cows that freshened earlier than expected for various reasons. Milk yields subsequent to unplanned short dry periods likely are less than the yields which follow planned, short or long, dry periods, in part, because with the planned scenario, the dairy farmer manages the cow to best prepare her to transition into a profitable lactating state by monitoring her body condition and providing an appropriate dietary regimen as calving approaches. Thus, results obtained using the retrospective data analysis approach are biased in favor of identifying the 60-d dry period as being more beneficial, in terms of subsequent milk yields, than the 30-d dry period.

To illustrate the bias that can exist in data analyzed retrospectively to determine optimal dry period length, an observation reported by Schaeffer and Henderson (1972) as well as by Smith and Becker (1995) will be evaluated, namely, that dry periods $>70 \mathrm{~d}$ in length had a large negative effect on subsequent milk production. In reality, failure to adjust the subsequent milk yield data for previous milk production interfered with the accurate detection of the effect, positive or negative, that long dry period lengths might have on subsequent milk production. Lower producing cows tend to have longer dry periods (Schaeffer and Henderson, 1972; Funk et al., 1987; Makuza and McDaniel, 1996). Therefore, the lactation yields achieved after longer dry periods will be lower, in part, due to the lower genetic ability of cows to produce milk rather than entirely due to effects associated with longer dry period lengths. Thus, conclusions based on results obtained from the analysis of observational data must be evaluated with a degree of skepticism due to the biases that can result from the inherent nonrandom assignment of cows to each dry-period category reported. In fact, Schaeffer and Henderson (1972) indicated that an accurate estimate of the heritability of days dry can only be obtained from records of cows that were allowed to go dry on their own accord, but they noted that those records cannot be discerned from the records of cows that were deliberately dried. The inability to determine, within a compilation of records, the reason why a particular days-dry value occurred would also interfere with the accurate estimation of the effect of days dry on subsequent milk production. 
Table 3. Factors that can affect milk yield subsequent to a dry period of any given length.

a) Herd

b) Year

c) Season/Heat stress

d) Cow (Herd)

e) Breed

f) Parity

g) Diet

h) Body condition

i) Health (digestive, reproductive, mammary, locomotive)

j) bST use protocol

k) Milk removals/day

1) Previous milk yield

m) Days open (previous)/Calving interval

n) Days open (current)

o) Days dry

\section{FACTORS THAT AFFECT MILK YIELD}

Milk yield is affected by many factors other than the number of days dry (Table 3; Wiggans et al., 2002). Therefore, those sources of variation in milk yield must be considered when the effect of days dry on subsequent milk yield is evaluated. Many of the earlier retrospective studies, upon which the current industry standard for dry period length is largely based, did not recognize or consider those factors (Table 1).

\section{DRY PERIOD REQUIRED}

Each successful reproductive cycle of the dairy cow produces a calf or calves at the onset of a potentially copious lactation. A nonlactating period (dry period) incorporated between successive lactations allows the mammary epithelial component to regress, proliferate, and differentiate which, in turn, allows maximal milk production to occur during the subsequent lactation (Capuco et al., 1997).

The remodeling of mammary tissue that occurs during the dry period is significant and important because absence of a dry period results in reduced milk production during the lactation that follows parturition (Swanson, 1965; Smith et al., 1966; Remond et al., 1997). To illustrate, Remond et al. (1997) observed that dairy cows managed without a dry period $(n=13)$ produced $5.6 \mathrm{~kg}$ less milk per day in comparison with their herdmates $(\mathrm{n}=18)$ managed with a $60-\mathrm{d}$ dry period. That reduction equated to a $22 \%$ decrease in total lactation milk yield.

Notably, the first animal experiment that attempted to control the genetic and management factors, which might affect milk yield beyond days dry (see Table 3), compared five sets of identical twins under similar nutritional management (Swanson, 1965). One twin of each set was allowed $60 \mathrm{~d}$ dry while the other twin was milked continuously. During the dry period phase, each set of twins consumed the same base diet, although the twin within each set that lactated continuously throughout her theoretical dry period received supplemental grain concentrates. The continuously lactating twins produced 25 and $38 \%$ less milk, respectively, in the second and third lactations compared with their respective twins allowed interceding 60-d dry periods. That experiment was also the first to establish that the negative effect of continuous milking on the next lactation was more likely attributed to effects on the mammary gland and its regulating factors than to nutritional factors.

Smith et al. (1967) eliminated all genetic and most management factors that affect subsequent milk production by comparing the milk yields of contralateral mammary quarters. The postpartum production of milk by the two mammary quarters that had been milked throughout the dry period phase was compared with the production of the other two quarters within the same mammary gland that had not been milked for $60 \mathrm{~d}$ before parturition. Although limited to two cows, results affirmed the necessity of a dry period, as the quarters not allowed a dry period produced 44 and $38 \%$ less milk during the subsequent lactation than their counterparts that had a 60-d dry period. Those results confirmed the conclusion of Swanson (1965) that the effect of dry period on subsequent milk yield cannot be solely attributed to nutritional factors. In addition, because mammary tissue exposure to hormonal factors was considered to be similar for all mammary quarters, Smith et al. (1967) suggested that the dry period effect on subsequent production appeared to be related to changes that originated within the mammary gland itself and took effect before parturition.

\section{OPTIMAL DRY-PERIOD LENGTH}

Whereas the need for a dry period to sustain subsequent milk production in dairy cows has been established (Swanson, 1965; Smith et al., 1966; Remond et al., 1997), determination of its optimal length continues to be investigated through the use of observational and experimental data. Most studies have used observational data because large numbers of historical lactation records are available from their compilation through organized record-keeping programs; primarily those administered through DHI. The major criticism of the retrospective use of observational data to determine optimal dry period length is the failure to have had days dry assigned at random, particularly irrespective of milk yield at drying (Sorenson and Enevoldson, 1991). In contrast, experimental datasets have been generated from designed animal experiments in which cows were assigned specific target days 
dry at random (Coppock et al., 1974; Sorenson and Enevoldson, 1991; Remond et al., 1997; Schairer, 2001; Bachman, 2002; Gulay et al., 2003). Researchers who have used observational data have attempted with varying degrees of success to correct their analyses for the biases that are associated with the nonrandom assignment of cows to days dry.

Within the dairy industry, the general recommendation and consensus is that cows should have a dry period of 50 to $60 \mathrm{~d}$ (O'Connor and Oltenacu, 1988), with the caveat that cows completing their first lactations benefit more from greater days dry than do older cows (Wilton et al., 1967; Schaeffer and Henderson, 1972; Dias and Allaire, 1982; Funk et al., 1987). It is anticipated that the milk income that is lost during the interceding 50 to $60 \mathrm{~d}$ nonlactating period will be recovered during the subsequent lactation, the productivity of which has been enhanced because the mammary tissue was allowed to involute and redifferentiate during the dry period (Capuco et al., 1997; Wilde et al., 1997).

\section{DETERMINANTS OF ACTUAL DRY PERIOD LENGTH}

Adjustment of milk production records with factors based on the heritability estimates of previous days open, previous days dry, or current days open was not warranted because those variables are largely controlled through management decisions, not via genetics (Wilton et al., 1967; Schaeffer and Henderson, 1972; Funk et al., 1987). That conclusion strengthens the argument that previous dry period length is the result of a management decision that, in turn, was influenced by many factors. Among these factors are relative cow productivity, reproductive status, health status, and available farm resources in terms of parlor pressure, feed supply, facilities, labor, and pregnant replacement heifers as well as uncontrolled events such as late gestation abortion, early parturition, unintended postponement of drying, and incorrect conception date. Normal gestation length of Holstein cows is estimated at $278 \mathrm{~d}$ (DHI glossary) with a standard deviation of $7 \mathrm{~d}$ (Coppock et al., 1974). Consequently, approximately $70 \%$ of cows dried $60 \mathrm{~d}$ before their expected calving dates would have a normal parturition, induced naturally within the range of 53 to 67 d dry.

When drying is initiated based on the failure of a cow to maintain a set minimum for daily milk yield, a bias will exist in the relationship between previous days dry and subsequent milk production because dry period length was not assigned at random irrespective of milk yield at drying. In practice, milk yield is gener- ally used to determine when a cow will be dried in preference to goals set by the dairy manager for length of dry periods.

A survey of 1040 New York dairy farmers revealed that $85 \%$ had a target goal for dry period length of 51 to $60 \mathrm{~d}$, whereas 10 and $5 \%$ had respective goals for days dry of 40 to $50 \mathrm{~d}$ and 61 to $75 \mathrm{~d}$ (O'Connor and Oltenacu, 1988). Thus, it follows that most of the surveyed dairy farmers had the recommended 51 to $60 \mathrm{~d}$ dry period length as their goal for the time drying cows, i.e., cows in the milking herd to be dried based on 51 to $60 \mathrm{~d}$ before expected calving date. Other cows in the milking herd will be dried earlier than dictated by their expected calving date because their milk production is below the minimum production criterion used by the dairy farmer. Such cows are referred to as production-level dry cows in contrast to cows dried based on expected calving date. The milk production levels used in 1988 by surveyed dairy farmers as guidelines for drying cows based on production ranged from $<6.8 \mathrm{~kg} / \mathrm{d}$ for $25 \%$ of herds to $>13.6 \mathrm{~kg} / \mathrm{d}$ for $5 \%$ of herds, whereas $60 \%$ of herds were within an intermediate range of 7.3 to $9.1 \mathrm{~kg} / \mathrm{d}$ and $10 \%$ of herds were between 9.5 to $13.6 \mathrm{~kg} / \mathrm{d}$. Therefore, lower producing herdmates would tend to have longer dry periods because they are more likely to be dried before they reach the timed goal used by the dairy manager based on expected calving date. Smith and Henderson (1972) noted and were cited subsequently by Makuza and McDaniel (1996) that the highest yielding cows had the shortest subsequent dry periods. In light of that observation, Makuza and McDaniel (1996) concluded that previous milk yield should be included in the model when effect of days dry on subsequent milk yield is determined. It should be understood that the shortest dry periods to which Smith and Henderson (1962) referred were still equal to or greater than the minimal number of days dry within the recommended timed dry goal, i.e, $\geq 51 \mathrm{~d}$ and within the goal of 51 to $60 \mathrm{~d}$ dry.

Low production levels during the current lactation will tend to increase days dry beyond the goal for time of drying and thus bias the relationship that exists between days dry and subsequent milk production such that less milk production during the subsequent lactation becomes associated with increased previous days dry. Inclusion of previous milk yield as a covariate helps to attenuate such a bias (Makuza and McDaniel, 1996). Alternatively, factors that contribute to decreased milk production that follows shorter dry periods obviously include insufficient time for the beneficial changes within the mammary gland to occur (Capuco et al., 1997; Remond et al., 1997; Wilde et al., 1997) and possibly inadequate time for replenishment of body condition. 
Most dairy managers have $>40 \mathrm{~d}$ dry as their timed dry goal and $>6.86 \mathrm{~kg} / \mathrm{d}$ as their guide for drying based on production (O'Connor and Oltenacu, 1988). Thus, cows that have $<40 \mathrm{~d}$ dry are likely cows that produced greater than the production dry minimum (at least $>6.86 \mathrm{~kg} / \mathrm{d}$ ) in order to have been milked close to the timed dry goal yet freshened earlier than expected for some unforeseen reason. Freshening earlier than expected could be the result of several factors including an inaccurate conception date or a late-term abortion. If freshening occurs earlier than expected, the milk yield of the dam can often be depressed as the mammary gland may not have been allowed sufficient time for involution and redifferentiation to occur. Although milk yield may be depressed from the earlier freshening, or from associated health events, such cows might still produce sufficient milk to be productive members of the herd for at least a portion of the subsequent lactation. From studies in which dry periods were omitted or severely reduced, it is known that milk production is decreased in the following lactation (Coppock et al., 1974; Makuza and McDaniel, 1996; Remond et al., 1997). Notably, any cows that have diminished production values following abnormal calving events, i.e., unplanned shortened dry periods, become part of the DHI records associated with shorter days dry.

The above scenario would contribute to the decreased subsequent milk production associated with $<40$ d dry when observational data are analyzed retrospectively. Consequently, when interpreting results based on observational data, it is inappropriate to conclude that the decreased milk production subsequent to $<40 \mathrm{~d}$ dry is related entirely to a lack of sufficient time for the mammary gland to involute and redifferentiate.

\section{OBSERVATIONAL DATA STUDIES}

As indicated above, both observational and experimental datasets have been used to determine the effect of dry period lengths on milk production during the subsequent lactation. Although cow numbers were low, observational data from Jersey cows suggested that cows with $<30 \mathrm{~d}$ dry $(\mathrm{n}=9$ records) produced $573 \mathrm{~kg}$ less milk (2688 vs. $3259 \mathrm{~kg}$ ) in the subsequent lactation than cows with dry periods of 31 to $60 \mathrm{~d}$ (n $=22$ records) (Arnold and Becker, 1936). Data used in that early study were from cows milked during different years and from cows that calved during different seasons of the year. The maximum average daily milk production was $12 \mathrm{~kg}$; statistical analysis of the data was not performed.
In a more controlled study involving 1139 withincow comparisons gleaned from 15,442 DHI lactation records, Klein and Woodward (1943) suggested that the optimal dry period length to balance current milk loss with future milk gain for cows yielding $4545 \mathrm{~kg}$ and calving at 12 -mo intervals was $55 \mathrm{~d}$. The withincow comparisons indicated that $9.2 \%$ more milk was produced when the cows $(n=432)$ were dry 31 to 60 $\mathrm{d}$ than when those same cows had dry periods of 0 to $30 \mathrm{~d}$. A production increase of $4.3 \%$ existed for the within-cow comparisons $(\mathrm{n}=474)$ of 61 to $90 \mathrm{~d}$ versus 31 to $60 \mathrm{~d}$ dry. With animals sampled over consecutive years and seasons, environmental effects associated with year of lactation could have contributed to lactation yield differences for each cow. The possibility that uncontrolled environmental effects, in addition to days dry and calving interval which were considered in the experiment, influenced the lactation yields is supported by the low (0.5) within-cow repeatability for lactation yields (Funk et al., 1987; Makuza and McDaniel, 1996; Wiggans et al., 2002).

Two subsequent studies based on data from 2364 cows (Lee et al., 1961) and 3071 lactation records (Smith and Legates, 1962), suggested, respectively, that days dry had a negligible effect on milk yield and that days dry accounted for $<0.1 \%$ of the variation in milk yield. Notably, the regression curve calculated based on the 3071 records estimated that the respective milk yields associated with 0,60 , and $100 \mathrm{~d}$ dry were 5705,5773 , and $5796 \mathrm{~kg}$. The validity of these suggestions is, however, weakened because both studies had few records for cows with short dry periods. It was noted that nearly all of the cows had dry period lengths of 42 to $60 \mathrm{~d}$ (Lee et al., 1961) and that only $9.4 \%$ of the records related to dry periods $<40 \mathrm{~d}$. Additionally, $25 \%$ of the records were associated with dry periods $>80 \mathrm{~d}$ (Smith and Legates, 1962). Consequently, those datasets were considered to be of limited value in determining the effect of $<40 \mathrm{~d}$ dry on subsequent milk production.

Use of official production records ( $\mathrm{n}=31,606)$ of Holstein-Friesian cattle made on the Canadian Record of Performance Program for Dairy Cattle between September 1, 1960, and August 31, 1961, resulted in the determination that variation in preceding days dry accounted for $4.8 \%$ of the within-sire variation in milk production in second lactations but only $0.6 \%$ of the variation in later lactations (Wilton et al., 1967). The authors acknowledged that precise estimation of the heritability of days dry was not possible in their study; however, it was noted that dry period lengths appeared to be affected mainly by environmental rather than genetic factors. The suggestion was made that economic gains could be made by reducing the number of 
days cows are dry to approximately $60 \mathrm{~d}$ to avoid loss of valuable time in the productive life span of each cow. Thus, dry periods $>60 \mathrm{~d}$ should be avoided for economic reasons. The intra-sire regression of production on days dry indicated that relative to $60 \mathrm{~d}$ dry, production was decreased $1.8 \%$ for $30 \mathrm{~d}$ dry (5987 vs. $5878 \mathrm{~kg}$ of metabolizable energy) in greater than second-lactation cows. As in most other observational studies, the distribution of records among categories of dry-period lengths was not indicated.

Relative to the previous US studies, a greater number of lactation records from cows with $<40 \mathrm{~d}$ dry likely were among the 22,482 DHI records from the New York Dairy Records Processing Laboratory that were analyzed by Schaeffer and Henderson (1972). Subsequent lactation yield was decreased 610 and $230 \mathrm{~kg}$ (6190 and 6570 vs. $6800 \mathrm{~kg}$ ) for 20 to $29 \mathrm{~d}$ dry and 30 to $39 \mathrm{~d}$ dry compared with 50 to $59 \mathrm{~d}$ dry. Whereas a dry period of $<30 \mathrm{~d}$ decreased subsequent lactation milk yield, it was concluded that on a practical basis a dry period of 40 to $49 \mathrm{~d}(6700 \mathrm{~kg})$ did not differ from a dry period of 50 to $59 \mathrm{~d}$. Interestingly, the analysis also indicated a large negative effect of $>70 \mathrm{~d}$ dry on subsequent production. As noted previously, nonrandom assignment of cows to days dry, as occurred in that observational dataset, may not be ignored as a possible factor that contributed to the observation that long dry periods decreased subsequent milk production.

Illustrative of that concern is a more recent study published in a trade publication that was supportive of the current industry recommendation of 50 to $59 \mathrm{~d}$ dry and showed a similar decline in milk production following long dry periods (Smith and Becker, 1995). Upon closer review of the data, a dry period of 70 to $79 \mathrm{~d}$ had a more detrimental effect on the production of milk (7868 kg) than did dry periods $<39 \mathrm{~d}(8015 \mathrm{~kg})$, when compared to the recommended 50 to $59 \mathrm{~d}$ dry $(8392 \mathrm{~kg})$. Although the study used data from 123,181 cows in 808 herds, it appears that all the biases associated with nonrandom assignment of days dry were not considered during the retrospective analysis of those observational data.

Age at calving, calving interval, and daily milk production at $100 \mathrm{~d}$ prepartum were identified as variables that also influence optimal days dry when the DHIA data of 8981 Holstein dairy cows collected during 1975 to 1977 were analyzed (Dias and Allaire, 1982). The optimal dry period in that study was defined as the length that resulted in the highest average daily milk production for the two consecutive lactations that had the interceding dry period. This definition of optimal dry period differs from other studies in that it did not consider the optimal dry period to be the dry-period length that simply resulted in the highest cumulative milk production during the subsequent lactation. Fewer days dry were needed to maximize average daily milk yield over two consecutive lactations as cow age increased, calving interval increased, or milk production at $100 \mathrm{~d}$ prepartum decreased. For example, a first-lactation cow that freshened at 24 mo with a subsequent short calving interval and high milk yield at $100 \mathrm{~d}$ prepartum had the highest calculated optimal days dry (75 d) between the first and second lactations. For comparison, $30 \mathrm{~d}$ was the calculated optimal dry period length between the third and fourth lactations of a mature cow that began her third lactation at 48 mo of age, had a long calving interval, and a high milk yield at $100 \mathrm{~d}$ prepartum during her third lactation. Certain scenarios involving these same factors, resulted in calculated optimal days dry of $<10 \mathrm{~d}$.

The Northeast Dairy Record Processing Center (NEDRPC) was the source of the large datasets used by Keown and Everett (1986) and Funk et al. (1987) to estimate, respectively, that 50 to $59 \mathrm{~d}$ dry and 60 to $69 \mathrm{~d}$ dry were optimal dry period lengths to maximize milk production during the subsequent lactation. The conclusions of Keown and Everett (1986) are based on the analysis of DHI records collected from July 1980 through August 1984 that had respective distribution among the first through third lactations of $305,237,226,313$, and 157,498 records. Funk et al. (1987) used consecutive lactation records collected between 1974 and 1980 with a respective distribution of the records among lactations of $84,356,55,877$, and 34,018 . Unfortunately, neither study reported the distribution of records among the ranges of days dry that were evaluated to support the conclusions that an estimated 3.9\% (Keown and Everett, 1986) and 6.0\% (Funk et al., 1987) less milk was produced during second or third lactations following 30 to $39 \mathrm{~d}$ dry, relative to the production after the respective optimal days dry of 51 to $60 \mathrm{~d}$ and 60 to $69 \mathrm{~d}$. Estimates were based on the assumption that average production was $6000 \mathrm{~kg}$. Whether the biases that resulted from the nonrandom assignment of days dry to the cows within those observational datasets were attenuated by the large population size is unknown. One of those studies included previous milk yield as a covariate during their analyses in an attempt to account for possible differences in the genetic ability of cows to produce milk (Funk et al., 1987). Credibility of those studies is strengthened by the absence of the detrimental effect on subsequent milk yield that has been reported to occur when the dry period length exceeded $70 \mathrm{~d}$ (Schaeffer and Henderson, 1972; Smith and Becker, 1995).

As indicated previously, some researchers have been more successful than others in removing the biases 
inherent with the nonrandom assignment of dry periods to cows from their analysis of observational production records performed in order to determine optimal dry-period length. The analyses performed by Makuza and McDaniel (1996) are the most comprehensive among the many studies that have used observational datasets (Klein and Woodward, 1943; Smith and Legates, 1962; Wilton et al., 1967; Schaeffer and Henderson, 1972; Keown and Everett, 1986; Funk et al., 1987; Smith and Becker, 1995; Makuza and McDaniel, 1996). During their research to determine the effect of days dry on subsequent milk production, Makuza and McDaniel (1996) adjusted milk yields of subsequent lactations for previous lactation milk yield to account for genetic and permanent environmental effects. In addition to previous milk yield, both previous and current days open were identified as factors that affect milk yield during the subsequent lactation. It was concluded that an increase in previous or current days open, independent of previous milk yield, increased subsequent lactation yields. To accurately determine the effect of days dry on subsequent lactation yield, the milk yield of the following lactation should be adjusted for previous milk yield as well as for both previous and current days open. With the exception of Funk et al. (1987), the studies reviewed previously did not report the use of any of those adjustments.

Milk production records $(\mathrm{n}=11,452)$ collected during 1960 to 1990 from six herds located in North Carolina had 5128, 3518, and 2806 records from Holstein cows for lactations 1, 2, and 3, respectively (Makuza and McDaniel, 1996). The comparative population of Holstein cows provided records while managed in 97 herds throughout Zimbabwe from 1979 to 1986 and had a respective distribution of records among lactations of 6455,3555 , and 3296. Approximately $6.1 \%$ of the 3518 North Carolina second-lactation records had previous days dry $<50$, whereas $1.0 \%$ had days dry $<30 \mathrm{~d}$. Comparable percentages for dry-period lengths were significantly higher in the 3555 second-lactation Zimbabwean records with values of $30.5 \%<50 \mathrm{~d}$ and $11.3 \%$ $<30$ d. First-lactation cows that had $<30 \mathrm{~d}$ dry produced 11.8 and $10.7 \%$ less milk during their second 305 -d lactations than the 8831 and $5424 \mathrm{~kg}$ of milk produced by their respective counterparts in North Carolina and Zimbabwe that were allowed the determined optimal dry period of 60 to $69 \mathrm{~d}$. Thus, days dry $<30 \mathrm{~d}$ resulted in an estimated $11 \%$ decrease in the subsequent second-lactation milk production for both populations of first-lactation cows despite the probable differences in the genetic potential of the cows and the type and level of management decisions that were implemented in the two countries. Milk production was lower by 4.7 and $2.5 \%$ when the dry-period length of 30 to $39 \mathrm{~d}$ was compared to a length of 50 to $59 \mathrm{~d}$ dry within the respective second lactation data sets for North Carolina and Zimbabwe (Table 1).

Subsequent milk yield was maximal following 60 to $69 \mathrm{~d}$ dry and this range, it was noted, agreed with the accepted management recommendation of a 60-d dry period (Makuza and McDaniel, 1996). Unfortunately, the authors only included data for the dry period that separated the first and second lactations but did, however, indicate that similar results were obtained for the dry period between second and third lactations. Thus, their conclusion that milk yields for both cow populations were reduced for lactations that followed $<60$ to $69 \mathrm{~d}$ dry pertains to the dry period length that should be provided to first-lactation cows before the onset of their second lactations and, subsequently, before the onset the third lactation. In contrast, previous work has shown that first-lactation cows benefited more than multiparous cows from a longer dry period (Wilton et al., 1967; Schaeffer and Henderson, 1972; Dias and Allaire, 1982).

Makuza and McDaniel (1996) also indicated that current milk yields were more highly correlated with current days open than with previous days open or previous days dry. Such effects appear to be relatively small because the associated correlation coefficients presented for those variables were very low and not significant. Nonetheless, their observation indicated that there was a complex array of the management factors other than days dry that can influence milk yield.

Retrospective analysis of observational data is informative but careful interpretation must be performed with an understanding that the data analyzed were not generated from designed experiments that strived to control the variables beyond days dry that may influence lactation yields (Coppock et al., 1974; Sorensen and Enevoldsen, 1991; Sorenson et al., 1993).

\section{ANIMAL TRIAL DATA STUDIES}

As noted and summarized above, the animal experiments of Swanson (1965) and Smith et al. (1966) were the first animal-based experiments that attempted to control the extraneous genetic and management factors, beyond length of the dry period (see Table 3), which might affect milk yield. Importantly, those experiments, in addition to establishing that a dry period is needed to sustain subsequent milk production, demonstrated that biological processes that occurred within the mammary gland during the dry period had a profound effect on the amount of milk produced during the subsequent lactation. Before those experiments, the benefit derived from incorporation of a dry 
(rest) period between successive lactations was attributed to nutritional factors, including rumen recovery. Studies of Ackerman et al. (1967) and the more recent animal trial of Remond et al. (1997), as noted above, confirmed that dairy cows managed without a dry period produced less milk per day in comparison to their herdmates managed with a 60-d dry period.

Citing the limitations of the use of DHI records to determine the effect of days dry on subsequent milk yield, cows ( $\mathrm{n}=1583$ ) managed in 65 commercial herds were randomly assigned to dry periods that differed in length (Coppock et al., 1974). Cows were divided into dry period lengths of 20,30, 40, 50, and $60 \mathrm{~d}$, irrespective of their late lactation milk yields. Use of commercially managed cows proved to be problematic as only 38 of the original 65 herds completed the 42 mo experimental period; of those herds that remained in the study, 15 dropped the 20-d dry period because of concerns over decreased milk production during the ensuing lactation.

Furthermore, compliance within each assigned treatment of dry-period length was breached because cows were dried earlier than the planned timed dry period if their milk production dropped below $9.1 \mathrm{~kg} /$ $\mathrm{d}$. Within each treatment group, a range of $\pm 10 \mathrm{~d}$ was tolerated, which would permit, for example, production records in the designated 30-d dry group to contain cows actually dry from 20 to $40 \mathrm{~d}$. A consequence of those changes in experimental protocol was that actual average days dry before ensuing lactations among all treatment groups across the multiple lactation study only ranged from 54.0 to $68.4 \mathrm{~d}$. However, variations from protocol had the least impact on the lactation that followed the first dry period of the experiment, which did allow for mean dry periods close to planned lengths. For those cows, the group with planned 40-d dry periods ( $\mathrm{n}=306$, actual 40.9 -d dry) produced as much milk in the subsequent lactation as the cows with planned 50-d ( $\mathrm{n}=356 ; 50.5 \mathrm{~d}$ dry) and 60-d ( $\mathrm{n}=$ 383 ; 59.6 d dry) dry periods. In contrast, cows $(\mathrm{n}=$ 330) with <40 d dry produced an estimated $484 \mathrm{~kg}$ (7.2\%) less milk per 305-d lactation than cows $(\mathrm{n}=$ 1045) with >40-d dry (6226 vs. $6710 \mathrm{~kg} / 305 \mathrm{~d}$ ). The authors concluded that dry periods of 40 to $60 \mathrm{~d}$ resulted in maximum subsequent milk production, although interpretation of the data was compromised by the lack of statistical analyses.

Concurring with the need for planned animal experiments to quantify the effect of days dry on subsequent milk production, cows $(\mathrm{n}=366)$ managed in eight Danish herds were assigned at random to dry periods with lengths of 28, 49, or $70 \mathrm{~d}$. (Sorensen and Enevoldsen, 1991). Cows $(\mathrm{n}=115)$ which had $29.6 \pm 9.4 \mathrm{~d}$ dry produced $10.2 \%$ less milk per day through 84 DIM (22.0 vs. $24.5 \mathrm{~kg} / \mathrm{d})$ compared with cows $(\mathrm{n}=123)$ that were dry $49.9 \pm 7.2 \mathrm{~d}$. That difference, when extrapolated for $305 \mathrm{~d}$ of lactation, equated to a $762.5-\mathrm{kg}$ reduction in total lactation milk yield as a result of the decreased days dry. For comparison, reduced production values for 30 versus $60 \mathrm{~d}$ dry, as estimated from observational data reports, were 9 (Klein and Woodward, 1943), 9 (Schaeffer and Henderson, 1972), 4 (Keown and Everett, 1986), 6 (Funk et al., 1987), and 5\% (Makuza and McDaniel, 1996).

Total amounts of 4\% FCM forfeited in the current lactation by increasing dry period length from 29.6 to $49.9 \mathrm{~d}$ were 239 and $183 \mathrm{~kg}$ for first-lactation cows and older cows, respectively (Sorensen and Enevoldsen, 1991). Because subsequent lactational milk production by cows dry for $29.6 \mathrm{~d}$ was estimated to be reduced by $>239 \mathrm{~kg}$ relative to the production of cows with 49.9 d dry, the shorter dry period was not profitable in that experiment. Sorensen et al. (1993) incorporated those data into a computerized stochastic simulation program designed to estimate herd economics. Conclusions of the stochastic simulation analyses supported the use of 49-d dry periods for Danish herds.

Cows managed in a commercial herd were assigned to dry-period lengths of either $60 \mathrm{~d}$ or $30 \mathrm{~d}$ as part of an experiment (Bachman, 2002) to determine whether estrogen administered at the initiation of the dry period would accelerate mammary involution and thus allow the dry period to be shortened profitably (Athie et al., 1996; Athie et al., 1997). Cows that did not receive estrogen had dry periods of $57.3 \mathrm{~d}(\mathrm{n}=19)$ and $33.9 \mathrm{~d}(\mathrm{n}=15)$. Those cows subsequently produced actual 305-d milk yields of 9942 and $9669 \mathrm{~kg}$, respectively, and 305-d mature equivalent (ME) milk yields of 8987 and $9126 \mathrm{~kg}$. When actual 305-d milk yields for the previous lactation were included as a covariate to adjust for genetic and permanent environmental effects, the subsequent adjusted actual lactation yields were $9978 \mathrm{~kg}$ for cows with $57.3 \mathrm{~d}$ dry and $9799 \mathrm{~kg}$ for cows with 33.9 d dry. Respective ME milk yields were 9011 and $9214 \mathrm{~kg}$. Differences between group means ranged from $273 \mathrm{~kg}$ more milk produced by the cows dry for $57.3 \mathrm{~d}$ based on actual unadjusted 305-d milk yields to $203 \mathrm{~kg}$ more milk produced by cows dry for 33.9 d based on adjusted 305-d ME values. For all comparisons, however, no significant differences were detected between the subsequent milk yields values for cows dry $57.3 \mathrm{~d}$ versus those dry for $33.9 \mathrm{~d}$. Milk production forfeited during the previous lactation to achieve a dry period of 57.3 versus $33.9 \mathrm{~d}$ was estimated to be about $512 \mathrm{~kg}$, based on the last test date milk yield average $(21.9 \mathrm{~kg})$ for cows dry for $33.9 \mathrm{~d}$. Thus, even for the comparison that indicated that the cows allowed a longer dry period outperformed cows 
dry for only 33.9 d by $273 \mathrm{~kg}$, if allowed the $512-\mathrm{kg}$ production credit if the previous lactation had been extended by $23 \mathrm{~d}$, the adjusted amount would equal or exceed the production of cows dry for $57.3 \mathrm{~d}$. The net gain in milk yield of $239 \mathrm{~kg}$ (512 minus $273 \mathrm{~kg}$ ) by a cow dry for $33.9 \mathrm{~d}$ would result in an additional $\$ 52.00$ in milk income per cow based on a milk price of $\$ 10$ per hundred pounds (45.4 kg) raw milk.

Subsequent experiments (Schairer, 2001; Gulay et al., 2003) also observed that, without the use of estrogen at drying, cows with planned 30-d dry periods produced as much milk as herdmates that were given planned 60-d dry periods. The respective adjusted actual 305-d milk production values from those studies were $11,635(\mathrm{n}=10,32 \mathrm{~d}$ dry $)$ vs. $10,222(\mathrm{n}=9,61 \mathrm{~d}$ dry) and $9580(\mathrm{n}=29,31$ dry) vs. $9836(\mathrm{n}=27,61 \mathrm{~d}$ dry). Those within-trial milk production values did not differ.

\section{MAMMARY TISSUE STUDIES}

Both the number and activity of differentiated mammary epithelial cells are the ultimate determinants of the amount of milk synthesized and secreted. The optimal length of dry period in terms of subsequent milk production should be highly correlated with the minimal length of dry period needed to effect a maximization of the prerequisite number and activity of differentiated mammary epithelial cells. Traditionally, the sequential events occurring within bovine mammary tissue during a 60-d dry period were designated as active involution, steady-state involution, and differentiation with respective durations of approximately 21, 18, and $21 \mathrm{~d}$ (Smith and Todhunter, 1982; Hurley, 1989; Nickerson, 1989; Oliver and Sordillo, 1989). Thus, a dry period of $<40 \mathrm{~d}$ would be considered insufficient time for the sequential processes of involution and differentiation to occur (Hurley, 1989).

However, in contrast with rodents, the involution of bovine mammary tissue does not involve extensive detachment of mammary epithelial cells from the basement membrane with their subsequent sloughing into the alveolar lumina (Hurley, 1989). In fact, Swanson et al. (1967) based on comparisons of mammary weight, total mammary DNA content, and histology had concluded that little or no cellular involution occurred during dry periods that ranged from 15 to 75 $\mathrm{d}$ in length. Subsequently, analysis of histological changes during forced involution in Holstein or beef cows also showed little evidence for the loss of epithelial cells or alveolar structure between lactations (Holst et al., 1987; Akers et al., 1990). Furthermore, while a limited amount of apoptotic cell death was detected to occur in bovine mammary tissue during dry-period involution, most of the observed loss of secretory capability was attributed to the dedifferentiation of the surviving mammary epithelial cells (Wilde et al., 1997).

In concurrence, Capuco et al. (1997), using a combined evaluation of tissue morphology and total udder DNA, determined that throughout a 60-d dry period no net loss of mammary cells occurred, tissue area occupied by epithelium did not decline, and alveolar structures remained intact. However, based on the rate of tritiated thymidine incorporation into alveolar cells, the dry period was deemed important for the replacement of senescent alveolar cells before the next lactation. The cells that need to be replaced during the dry period might be those that are responsible for expanding and maintaining the number of secretory cells (Capuco and Akers, 1999).

The remodeling process within bovine mammary tissue involves apoptotic cell death and cell proliferation; both of which occur in a continuous manner throughout an established lactation. Although cell death exceeds cell proliferation, considerable turnover of mammary cells occurs during the lactation in that nearly all cells present in the mammary gland at the end of the lactation were formed after calving (Capuco et al., 2001). This observation could suggest that the remodeling of mammary tissue, which does occur during the dry period, does not need to be as extensive as previously thought. Consequently, although a dry period is needed to sustain subsequent milk production, its optimal length might be shorter than previously thought. Indeed, recent animal experiments suggest that a dry period of 30 to $40 \mathrm{~d}$ is sufficient to effect a maximization of the number and activity of differentiated mammary secretory cells within the modern dairy cow (Schairer, 2001; Bachman, 2002; Gulay et al., 2003).

\section{SUMMARY}

A dry period has been established as a necessary management practice to maintain profitable milk production in dairy cows. Failure to allow any dry period results in a significant decrease in milk synthesis and secretion (Swanson, 1965; Smith et al., 1967; Remond et al., 1997). Studies to determine the optimal length of the dry period that is required have involved the retrospective analysis of observational data or the conduct of experiments with dairy cows assigned, at random, to planned lengths of the dry period. Estimates of the change in subsequent milk production when dry periods were decreased from a range of 50 to $57 \mathrm{~d}$ to 30 to $34 \mathrm{~d}$ have ranged from a 10\% decrease (Sorensen and Enevoldsen, 1991) to a $1 \%$ increase (Bachman, 
2002). Dated studies have concluded that the optimal dry period length, that results in little or no loss in subsequent milk production, is 40 to $60 \mathrm{~d}$ (Arnold and Becker, 1936; Klein and Woodward, 1943; Schaeffer and Henderson, 1972; Coppock et al., 1974; Dias and Allaire, 1982; Keown and Everett, 1986; Funk et al., 1987; Sorensen and Enevoldsen, 1991; Makuza and McDaniel, 1996). Refinement of that optimal range is needed and must consider the complex array of environmental factors that influence milk production (Table 3) as well as the biological processes that occur within the mammary gland during the nonlactating period (Capuco et al., 1997; Wilde et al., 1997). Importantly, additional animal trials that assign cows randomly to the dry period lengths that are being evaluated are needed to determine the optimal dry period length for the modern dairy cow in various management scenarios.

\section{REFERENCES}

Ackerman, R. A., R. O. Thomas, and D. F. Butcher. 1967. Effect of length of dry period on production. J. Dairy Sci. 50:976977(Abstr.).

Akers, R. M., W. E. Beal, T. B. McFadden, and A. V. Capuco. 1990. Morphometric analysis of involuting bovine mammary tissue after 21 or 42 days on non-suckling. J. Anim. Sci. 68:3604-3613.

Arnold, P. T. D., and R. B. Becker. 1936. Influence of preceding dry period and of mineral supplement on lactation. J. Dairy Sci. 19:257-266.

Athie, F., K. C. Bachman, H. H. Head, M. J. Hayen, and C. J. Wilcox. 1996. Estrogen administered at final milk removal accelerates involution of bovine mammary gland. J. Dairy Sci. 79:220-226.

Athie, F., K. C. Bachman, H. H. Head, M. J. Hayen, and C. J. Wilcox. 1997. Milk plasmin during bovine mammary involution that has been accelerated by estrogen. J. Dairy Sci. 80:1561-1568.

Bachman, K. C. 2002. Milk production of dairy cows treated with estrogen at the onset of a short dry period. J. Dairy Sci. 85:797-803.

Capuco, A. V., and R. M. Akers. 1999. Mammary involution in dairy animals. J. Mammary Gland Biol. Neoplasia 4:137-144.

Capuco, A. V., R. M. Akers, and J. J. Smith. 1997. Mammary growth in Holstein cows during the dry period: Quantification of nucleic acids and histology. J. Dairy Sci. 80:477-487.

Capuco, A. V., D. L. Wood, R. Baldwin, K. McLeod, and M. J. Paape. 2001. Mammary cell number, proliferation and apoptosis during the lactation cycle: Relationship to milk production and effect of bST. J. Dairy Sci. 84:2177-2187.

Coppock, C. E., R. W. Everett, R. P. Natzke, and H. R. Ainslie. 1974. Effect of dry period length on Holstein milk production and selected disorders at parturition. J. Dairy Sci. 57:712-718.

Dias, F. M., and F. R. Allaire. 1982. Dry period to maximize milk production over two consecutive lactations. J. Dairy Sci. 65:136-145.

Funk, D. A., A. E. Freeman, and P. J. Berger. 1987. Effects of previous days open, previous days dry, and present days open on lactation yield. J. Dairy Sci. 70:2366-2373.

Goff, J. P., and R. L. Horst. 1997. Physiological changes at parturition and their relationship to metabolic disorders. J. Dairy Sci. 80:1260-1268.

Gulay, M. S., M. J. Hayen, K. C. Bachman, T. Belloso, M. Liboni, and H. H. Head. 2003. Milk production and feed intake of Holstein cows given short $(30 \mathrm{~d})$ or normal $(60 \mathrm{~d})$ dry periods. J. Dairy Sci. 86:2030-2038.
Holst, B. D., W. L. Hurley, and D. R. Nelson. 1987. Involution of the bovine mammary gland: histological and ultrastructural changes. J. Dairy Sci. 70:935-944.

Hurley, W. L. 1989. Mammary function during involution. J. Dairy Sci. 72:1637-1646.

Keown, J. F., and R. W. Everett. 1986. Effect of days carried calf, days dry and weight of first calf heifers on yield. J. Dairy Sci. 69:1891-1896.

Klein, J. W., and T. E. Woodward. 1943. Influence of length of dry period upon the quantity of milk produced in the subsequent lactation. J. Dairy Sci. 26:705-713.

Lee, J. E., O. T. Fosgate, and J. L. Carmon. 1961. Some effects of certain environmental and inherited influences upon milk and fat production in dairy cattle. J. Dairy Sci. 43:296-299.

Makuza, S. M., and B. T. McDaniel. 1996. Effects of days dry, previous days open, and current days open on milk yields of cows in Zimbabwe and North Carolina. J. Dairy Sci. 79:702-709.

National Agricultural Statistical Service. 2001. Milk production, disposition and income summary. Online. Available: http:// www.usda.gov/nass/.

Nickerson, S. C. 1989. Immunological aspects of mammary involution. J. Dairy Sci. 72:1665-1678.

O'Connor, J. J., and P. A. Oltenacu. 1988. Determination of optimum drying off time for dairy cows using decision analysis and computer simulation. J. Dairy Sci. 71:3080-3091.

Oliver, S. P., and L. M. Sordillo. 1989. Approaches to the manipulation of mammary involution. J. Dairy Sci. 72:1647-1664.

Remond, B., J. Rouel, N. Pinson, and S. Jabet. 1997. An attempt to omit the dry period over three consecutive lactations in dairy cows. Ann. Zootech. 46:399-408.

Schaeffer, L. R., and C. R. Henderson. 1972. Effects of days dry and days open on Holstein milk production. J. Dairy Sci. 55:107-112.

Schairer, M. L. 2001. Estrogen treatments for the initiation of dryoff in dairy cows. M.S. Thesis. Univ. Florida, Gainesville.

Smith, A., J. V. Wheelock, and F. H. Dodd. 1966. Effect of milking throughout pregnancy on milk yield in the succeeding lactation. J. Dairy Sci. 49:895-896.

Smith, J., and K. Becker. 1995. 50 to 59 days dry has highest production. Page 6 in Hoards Dairyman, Fort Atkinson, WI.

Smith, J. W., and J. E. Legates. 1962. Relation of days open and days dry to lactation milk and fat yields. J. Dairy Sci. 45:1192-1198.

Smith, K. L., and D. A. Todhunter. 1982. The physiology of mammary gland during the dry period and the relationship to infection. Pages 87-93 in Proc. 21st Annu. Mtg., Natl. Mastitis Counc., Inc., Louisville, KY.

Sorenson, J. T., and C. Enevoldsen. 1991. Effect of dry period length on milk production in subsequent lactation. J. Dairy Sci. 74:1277-1283.

Sorenson, J. T., C. Enevoldsen, and T. Kristensen. 1993. Effects of different dry period lengths on production and economy in the dairy herd estimated by stochastic simulation. Livest. Prod. Sci. 33:77-90.

Swanson, E. W. 1965. Comparing continuous milking with sixty-day dry periods in successive lactations. J. Dairy Sci. 48:1205-1209.

Swanson, E. W., F. E. Pardue, and D. B. Longmire. 1967. Effect of gestation and dry period on deoxyribonucleic acid and alveolar characteristics of bovine mammary glands. J. Dairy Sci. 50:1288-1292.

Wiggans, G. R., P. M. VanRaden, J. Bormann, J. C. Philpot, T. Druet, and N. Gengler. 2002. Deriving lactation yields from testday yields adjusted for lactation stage, age, pregnancy, and testday class. J. Dairy Sci. 85:264.

Wilde, C. J., C. V. P. Addey, P. Li, and D. G. Fernig. 1997. Programmed cell death in bovine mammary tissue during lactation and involution. Exp. Physiol. 82:943-953.

Wilton, J. W., E. B. Burnside, and J. C. Rennie. 1967. The effect of days dry and days open on milk and butterfat production of Holstein-Friesian cattle. Can J. Anim. Sci. 47:85-90.

Woodward, T. E., and J. R. Dawson. 1926. Care and management of dairy cows. USDAF Bull. 1470:2. 